\title{
Impact of Participation in the Family Income Generating Program (UPPKS) on Women's Sustainable Livelihoods in Serdang Bedagai District of North Sumatra
}

\author{
Muba Simanihuruk \\ Department of Sociology \\ University of Sumatera Utara \\ Medan, Indonesia \\ muba@usu.ac.id
}

\author{
Henri Sitorus \\ Department of Sociology \\ University of Sumatera Utara \\ Medan, Indonesia \\ henri@usu.ac.id
}

\begin{abstract}
BKKBN implements a family welfare income generating program (UPPKS) associated with the implementation of Family Planning (KB).This article aims to analyze the impact of the UPPKS program on the welfare and livelihoods of women beneficiaries of the UPPKS program in Serdang Bedagai District, North Sumatra. The UPPKS program is a priority program for BKKBN centers its local government units to reduce poverty rates among women. Indeed, women's economy is still remains the most vulnerable, compare to their male's counterpart. Women's access to productive resources are lower as well as their access to other economic opportunities, political institutions and others essential services.
\end{abstract}

This research uses mixed methods (combination of quantitative and qualitative methods). The research findings show that UPPKS network participants have improved both horizontally or vertically as well as with consumers. However, the program has had little impact in improving the welfare of women's groups so that their sustainable livelihoods remain vulnerable. This is due to the small scale nature of the productive managed and limited market network. The publication of this article as well as the field research is supported by the USU Research Institute.

Keywords-empowerment, uppks, livelihood, social capital

\section{INTRODUCTION}

Poverty remains a challenge in social development of Indonesia. There is still high number of population living below poverty line. In March 2017, according to BPS, the number of poor people in Indonesia reached 27.77 million people (10.64 percent). The category of poverty that used is still focused on the income poverty, where in 2016, the poverty line in rural areas is at $\mathrm{Rp} 350,420$. While for urban poverty uses $\mathrm{Rp} 372,114$ as poverty line. If the international standard of USD 2 per day is used, $40 \%$ of population in Indonesia is poor (ADB, 2015).

Various studies have noted that women is considered as most vulnerable and marginalized group in the society. Compare to men, women tend to have less access to productive resources, social service, economic opportunities and development benefits (Nurdin, 2006). Therefore, various empowerment programs are targeting women's groups. Gender gaps still exist in Indonesia in various sphere of social, health, economic and politics. Marginalization of women's employment is still common, and the most vulnerable households are headed by women. Women are also often perceived to be subordinate, and concentrated in low paying jobs, including in the informal sector (UNFPA, 2014). According to Indonesia's Ministry of Women's Empowerment, women tend to concentrate in the informal sector, so that $70 \%$ of informal sectors workers are women (Menegpp, 2014). This indicates that women face difficulties or constraints in accessing formal employment, and women tend to enter the informal sector due to the flexibility of its working conditions. The phenomenon of heavy involvement of women in the informal economy is an indication of women's subordination in economic, social and political realm (Muttaqin, 2014).

The Strategic Plan of the BKKBN for 2015-2019 mandates the target of family economic empowerment as one of the priority agenda. The UPPKS program of the BKKBN is one among key interventions to improve the family well-being which is ultimately expected to increase participation in family planning programs. Through the UPPKS program, the productive economic activities are strengthened with trainings, information and business development supports (BKKBN, 2005, BKKBN 2014).

The stages of UPPKS program include: (1) conducting analysis of capability, mapping condition and economic potential of the region; (2) Preparation the action plan for poor and nearly poor communities as set forth in the RPJMD (development plan); (3) Establish UPPKS group; (4) training on economic empowerment for UPPKS group and management; (5) enhancement of access to information and fostering productive economic; (6) Assisting in access to financial capital, production and marketing; (7) provide family planning services; (8) Providing technical assistance; (9) 
fostering family planning and improving self-reliance and (10) monitoring and evaluation.

Previous studies have documented the impact of participation in UPPKS on family planning and income generation. Heryendi'sstudy (2013) shows that UPPKS program includes successfully enhanced economic well-being of $86 \%$ of women participating in the program. After participating in the program, participants increasedtheir income (Heryendi, 2013). However, according to Iswarati et. Al (2012), not all of the interventions resulted in successful economic leverage, this is because of low access to financial capital.

\section{Social CAPITAL AND LiVElihoods}

Livelihood strategy is a variety of activities or efforts undertaken by the family to meet theirdaily needs. Livelihood approach is a perspective to analyze how communities sustain their jobs, earn living and how they cope with various stress and deprivation.

Chambers and Conway (1992:6) argue that "livelihood comprises the capabilities, assets (including both material and social resources) and activities required for a means of living. A livelihood is sustainable when it can cope with and recover from stresses and shocks and maintain or enhance its capabilities and assets both now and in the future." Livelihood assets generally are a function of interplay among different types of capital: social capital, natural capital, financial capital, physical capital and human capital (Scoones, 2009); and are mediated by institutions, social relations and agency (Ellis, 2000).The sustainable livelihoods framework provides holistic analysis of various factors that affect livelihoods outcomes. However, the capitals originally listed do not include political capital. It is claimed that the interaction between capitals will affect the structure and process of livelihoods including institutions, policies and legislation (DFID, 1999). This process will lead to diversity of livelihood strategies in which individuals and households can pursue diverse means for their livelihoods. The linkages of various factors in building sustainable livelihoods can be seen in the following figure.
Figure 1: Sustainable Livelihoods Framework

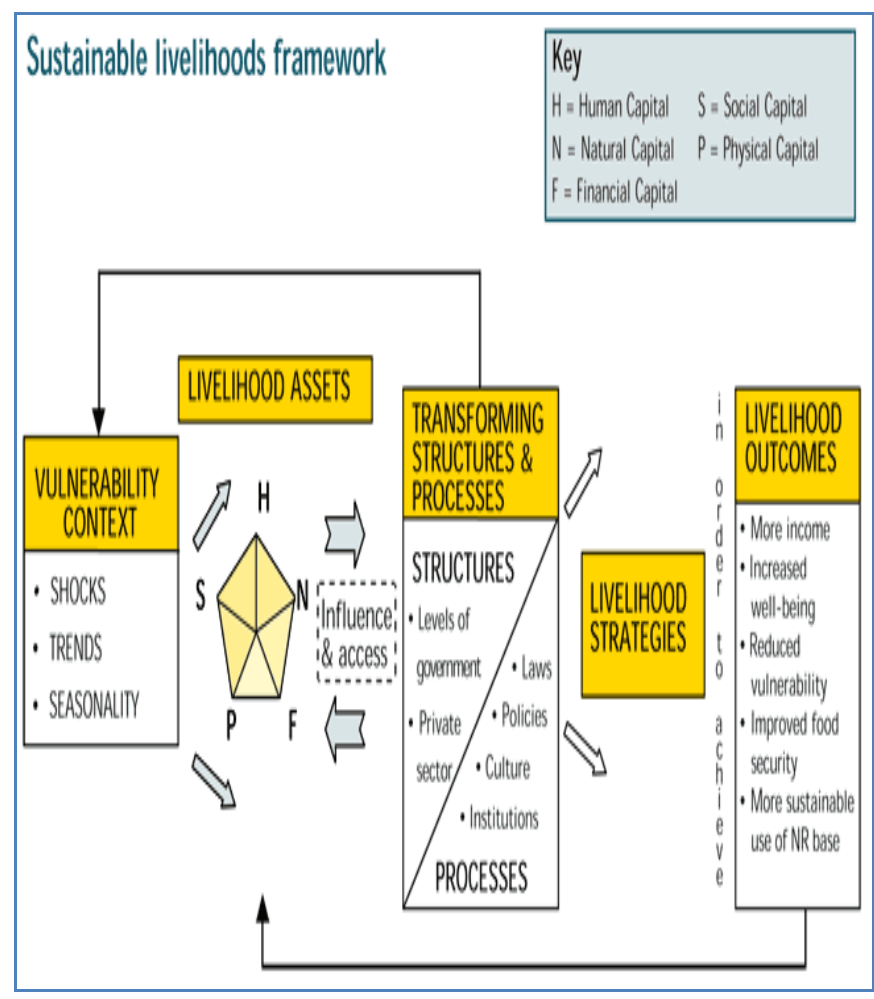

Source: Saragih, Lassa dan Ramli (2007:3)

\section{PARTICIPATION IN THE UPPKS PROGRAM AND WOMEN EMPOWERMENT}

Participation is the key to successful socio-economic development. Arnstein (1969) has identified several stages of participation in the ladder of participation. The lowest ladder means that there is no participation yet. Although it has become a developmental jargon, the fact is that participation is often take place at the level of socialization if not manipulation. The highest level of participation, according to Arnstein, take place if the community can fully control a program.

Table 1. Level of Participation

\begin{tabular}{|c|c|c|c|}
\hline Lvl. & Category & Description & Main cluster \\
\hline 1 & $\begin{array}{l}\text { Manipulatio } \\
n\end{array}$ & $\begin{array}{l}\text { Decision making } \\
\text { is totally } \\
\text { controlled by the } \\
\text { government }\end{array}$ & \multirow{2}{*}{$\begin{array}{l}\text { No } \\
\text { participation }\end{array}$} \\
\hline 2 & Therapy & $\begin{array}{l}\text { Only to avoid } \\
\text { anger of the } \\
\text { community }\end{array}$ & \\
\hline 3 & Informing & $\begin{array}{l}\text { One way } \\
\text { socialization }\end{array}$ & \multirow[b]{2}{*}{$\begin{array}{l}\text { Tokenism/ju } \\
\text { st to get } \\
\text { agreement }\end{array}$} \\
\hline 4 & Consultation & $\begin{array}{l}\text { Community is } \\
\text { able to raise } \\
\text { concern, but not } \\
\text { heard }\end{array}$ & \\
\hline
\end{tabular}


Table 1, cont.

\begin{tabular}{|c|c|c|c|}
\hline . & Placation & $\begin{array}{l}\text { Suggestion from } \\
\text { community is } \\
\text { accepted but not } \\
\text { implemented }\end{array}$ & \\
\hline . & Partnership & $\begin{array}{l}\text { Negotiated } \\
\text { feedback }\end{array}$ & \multirow{3}{*}{$\begin{array}{l}\text { Control lies } \\
\text { at the } \\
\text { community }\end{array}$} \\
\hline . & $\begin{array}{l}\text { Delegated } \\
\text { Power }\end{array}$ & $\begin{array}{l}\text { Some form of the } \\
\text { control is given }\end{array}$ & \\
\hline 8 & $\begin{array}{l}\text { Community } \\
\text { Control }\end{array}$ & $\begin{array}{l}\text { Totally controlled } \\
\text { by the community }\end{array}$ & \\
\hline
\end{tabular}

Source: Arnstein, 1969; Rosyida, Isma. et. al. (2011).

The UPPKS program aims to enhance economic capability of the participants, and mostly women. Hence, the core activities of UPPKS is production improvement which lead to women's empowerment. Golla et.al (2011) notes that a woman is economically empowered when she has the ability to be successful, advance her economic activity, have the power to negotiate and contribute effectively in economic decisions. Furthermore, Taylor and Pereznieto (2014) defines empowerment as 'a multi-dimensional social process that helps people to gain control over their own lives'. Mayoux (2008) then argued that empowerment would result in a situation that disadvantaged groups would achieve the same rights, empowered and able to enhance access to resources.

\section{SOCIAL CAPITAL AND FINANCIAL RESOURCES}

The research finds that the benefits reported by the respondents of UPPKS enhance their social capital. This can be seen in the diagram in this section:

Graph 1: Increase of Social Capital

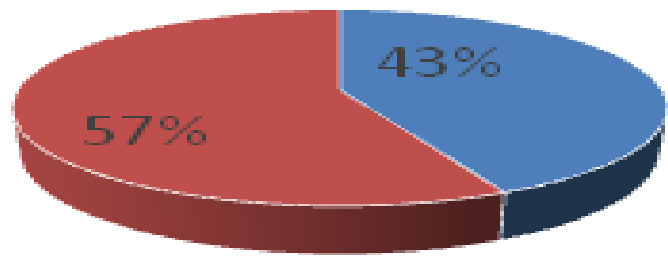

$$
\text { - Yes - No }
$$

Source: Field Research (2017)

The above diagram shows that respondents after participating the UPPKS program about $89 \%$ reported that their social network, relationship and linkage with external have improved. This means that most respondents reported that after joining the program theirfriends, relationship with other group members and institutional network have increased. This can be seen in the following diagram:
Enhanced Relationship with Different Agencies

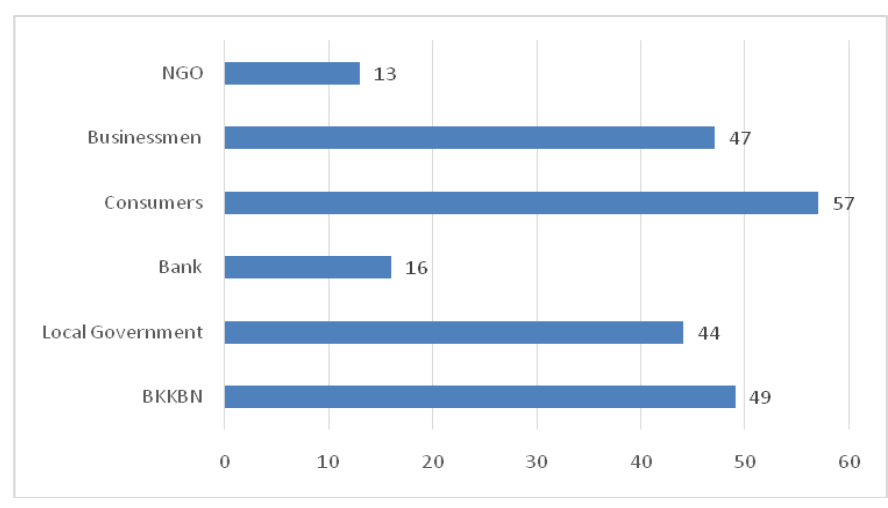

Source: Field Research (2017)

The above chart shows that 49 percent of the respondents reported that their relationship with BKKBN officials has increased after joining the program. In addition, $44 \%$ of the respondents reported that they have better relations with local government officials, and $57 \%$ of the respondents informed that their relationship with customer has increased. However, only $16 \%$ of the respondents acknowledged that their relations with bank has improved. Similarly, there is lower response for relationship with NGOs.

This study also reveals the impact of participation of respondents in the UPPKS program has enhanced access to mentorship program.

\section{Graph 2: Enhanced Access to Mentorship}

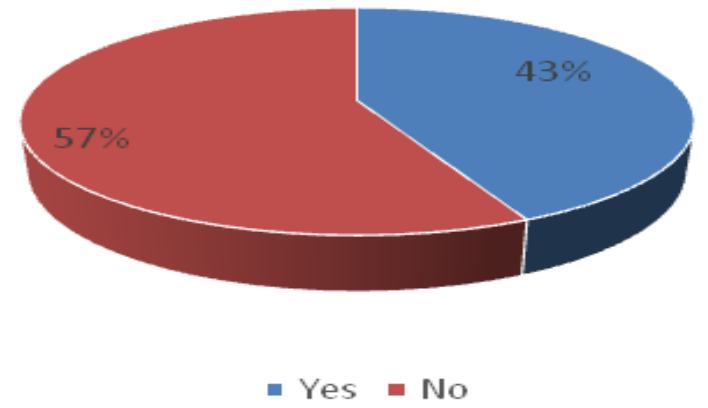

Source: Field Research (2017)

The chart shows that $43 \%$ of the respondents reported that they have gained benefits for easy access to mentor or technical service providers. However, majority of the respondents reported that their social capital for mentorship has nnot improved.

\section{ACCESS TO FINANCIAL RESOURCES}

Financial capital is central for successful livelihoods and economic empowerment in Indonesia. Microfinance offers poor people access to basic financial services, such as loans, 
savings, money transfer services, and micro-insurance (Hamada, 2010). Similarly, other resources and benefits contribute to poverty alleviation. Microfinance leverages the capacity for self-reliance. Increased access will result in control over income and increased well-being. It also improves the status and confidence of women, which in turn leads to better relations within the household (Mayoux, 2002).

The study reveals that there is still issue in terms of financial capital for women engage in UPPKS. Indeed, the most prominent issue of small business still concerns with the availability of business financing. Financial capital is required both in terms of starting and maintaining maintaining the business. Access of the participants to the financial services from Bank is still very limited. In fact, according to the World Bank (2010), only 31 percent of households in Indonesia are served by the informal and semi-formal financial sector. Furthermore, only 41 percent of households use bank savings. Bank of Indonesia in a survey (2010) found that $61.65 \%$ of households do not have savings.

The low access to credit from banks is evident in the study. Majority of the financial support are gained from extended families and neighborhoods. Although the respondents have savings, but for small business financial capital is not obtained from banks or cooperatives, but still heavily relied on extended family and neighbors. Only $7 \%$ of respondents acknowledge that when they need for financing business, they obtained supports from the cooperative.

\section{Source of Loan for Small-Business}

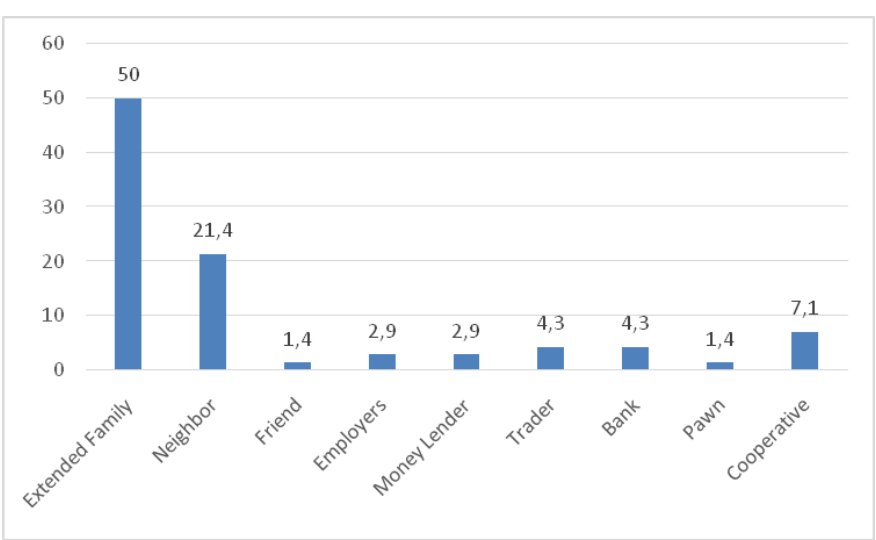

Source: Field Research (2017)

There is opportunity for mobilizing internal financial resources that can be mobilized within the UPPKS such as group saving and loans activities. However, all the respondents stated in the study that until 2017, no group has engaged in savings and loan activities, though there is effort to promote saving behavior.

\section{CONCLUSION}

SerdangBedagai in 2017. This group is a productive business group intended to empower the economy of women and families. The technical assistance is organized by the BKKBN. This study find that productive small-business run by UPPKS group are generally in a small scale size, using low technology (mostly manual) and generally having difficulty in obtaining raw materials. Women have diversified livelihoods through home industries, but often these activities are on a very small scale. Most of the production is manual, with limited access to or use of technology and limited marketing, uses low quality packaging and displays limited skills.

This study shows that participation in UPPKS increases social capital. The network of UPPKS participants has improved both with similar groups, networks with village government, sub-district governments and consumers. However, the improvement in the social capital has not affected increase in the financial capital.

\section{References}

[1] ADB (2015) Summary of Indonesia's Poverty Analysis. ADB Papers on Indonesia No. 04.

[2] Alkire, S., Foster, J., Seth, S., Santos, M. E., Roche, J. M., \& Ballon, P. (2015). Multidimensional poverty measurement and analysis: Oxford University Press, USA.

[3] Ashley, C. and Carney, D. (1999) Sustainable Livelihoods: Lessons from early experience. London: Department for International Development.

[4] Babbie, E. (2002). The practice of social research. Belmont, CA: Cengage Learning.

[5] BKKBN (2005) Peraturan Kepala BKKBN Nomor: 55/hk-010/b5/2010 tentang Standar Pelayanan Minimal Bidang Keluarga Berencana dan Keluarga Sejahtera di Kabupaten/Kota.

[6] BKKBN (2015) Rencana Strategis 2015 2019. Jakarta: Badan Kependudukan Dan Keluarga Berencana Nasional.

[7] Bogdan R.C. and Biklen S.K. (1982).Qualitative Research for Education: An Introduction to Theory and Methods. Toronto: Allyin and Bacon Inc.

[8] Carney, D. (1998).Sustainable rural livelihoods: what contribution can we make? Papers presented at the Department for International Development's Natural Resources Advisers' Conference. Paper presented at the Sustainable rural livelihoods: what contribution can we make? Department for International Development's Natural Resources Advisers' Conference, July 1998.

[9] Chambers, R., \& Conway, G. (1992). Sustainable rural livelihoods: practical concepts for the 21 st century. Institute of Development Studies (UK).

[10] Creswell, J.W. (1994). Research Design: Qualitative and Quantitative Approaches. Thousand Oaks, CA: Sage Publication, Inc.

[11] Creswell, J.W. dan Clark, V.L.P. (2011) Designing and conducting mixed methods research. Thousand Oaks, CA: Sage Publications, Inc.

[12] Creswell, J.W. dan, Clark, V.L.P. (2007) Designing and conducting mixed methods research. Thousand Oaks, CA:Sage Publications, Inc.

[13] De Vaus, D. (2002).Surveys in social research. Sydney: Allen and Unwin.

[14] DFID.(1999). Sustainable livelihoods guidance sheets. London: DFID.

[15] Ellis, F. (2000).Rural livelihood and diversity in developing countries. Oxford: Oxford University Press.

[16] Golla, A. M., Malhotra, A., Nanda, P., \& Mehra, R. (2011).Understanding and measuring women's economic empowerment: Definition, framework, indicators. Washington DC: International Centre for Research on Women.

[17] Heryendi, W. T. (2013). Efektivitas Program Usaha Peningkatan Pendapatan Keluarga Sejahtera (UPPKS) Di Kecamatan Denpasar Barat. Jurnal Ekonomi Kuantitatif Terapan, 6(2).

[18] Irawati et.al. (2012) Aksessibilitas Modal di Kalangan Kelompok UPPKS dalam Meningkatkan Usaha Kelompok di Kabupaten Gresik dan Malang, Provinsi Jawa Timur. 
[19] Iswarati, Winarni, E., Wahyuni, Hariastuti, Oktriyanto (2012). Insentif peningkatan kemampuan peneliti dan perekayasa aksesibilitas modal di kalangan kelompok UPPKS dalam meningkatkan usaha kelompok di Kabupaten Gresik dan Malang Provinsi Jawa Timur. Kementerian Ristek.

[20] Mack, N., Woodsong, C., MacQueen, K.M., Guest, G., and Namey, E. (2005). Qualitative research methods: A data collector's field guide. North Carolina: USAID - Family Health International.

[21] Marshall, C. \& Rossman, G.B. (2006) Designing qualitative research (4th. Ed). London: Sage.

[22] Mayoux, L. (2008). Module 3: Gender and Rural Finance' in Gender and Agriculture Source Book, World Bank, Washington DC.

[23] Morgan, D. L. (1988).Focus groups as qualitative research. London: Sage Publication.

[24] Morse, J. M. (2003). 'Principles of mixed methods and multi method research design'. In Tashakkori, A. and Teddlie, C. (eds.): Handbook of Mixed Methods in Social and Behavioral Research (pp. 189-208). Thousand Oaks, CA: Sage.

[25] Muttaqin, F. (2014) Women and Informal Economy in Indonesia: Dynamics and Transformation. http://www.academia.edu/3191981/Women_and_Informal_Economy_in _Indonesia_Dynamics_and_Transformation

[26] Narayan, D., Chambers, R., Shah, M. K., \& Petesch, P. (2000). Voices of the Poor: Crying out for Change. New York: Oxford University Press for the World Bank.

[27] Neuman, L. (2006) Social Research Methods: Qualitative and Quantitative Approaches. Boston: Pearson.

[28] Noerdin, E. (2006). Potret kemiskinan perempuan. Women Research Institute.

[29] Rosyida, Isma. et. al. (2011) Partisipasi Masyarakat dan Stakeholder dalam Penyelenggaraan Program Corporate Social Responsibility (CSR) dan Dampaknya terhadap Komunitas Perdesaan. Sodality: Jurnal
Transdisiplin Sosiologi, Komunikasi, dan Ekologi Manusia April 2011, hlm. 51-70.

[30] Saragih, dkk.2007.Kerangka Penghidupan Berkelanjutan http://www.zef.de/module/register/media/2390_SL-Chapter1.pdf

[31] Sarantakos, S. (2003). Social Research.Basingstoke: Palgrave Macmillan.

[32] Scoones, I. (2009). 'Livelihoods perspectives and rural development'. The Journal of Peasant Studies, 36(1), 171-196.

[33] Simanjuntak, M. (2014) Analisis Kelompok Usaha Peningkatan Pendapatan Keluarga Sejahtera di DKI Jakarta, 2014.BINUS BUSINESS REVIEW Vol. 5 No. 2 November 2014: 601-614

[34] Sitorus, H. Saragih, S. dan Agustin, R. (2016) Gender dan Studi Rantai Nilai Peternakan di NTT. Plan International.

[35] Sugiyanto, R., \& Upami, T. (2015). Makna Budaya Lokal Dalam Usaha Peningkatan Pendapatan Keluarga Sejahtera (UPPKS)(Studi Kasus Kelompok UPPKS di Kalimantan Tengah). JIPSINDO, 2(2).

[36] Susanti, I. (2014). Manfaat Hasil Penyuluhan Usaha Peningkatan Pendapatan Keluarga Sejahtera (UPPKS) Dalam Upaya Pemberdayaan Ekonomi Keluarga. FamilyEdu, 1(1).

[37] Taylor, G., \& Pereznieto, P. (2014).Review of evaluation approaches and methods used by interventions on women and girls' economic empowerment.Overseas Development Institute, 1-62.

[38] UNFPA (2014). Gender Equality and Gender-based Violence. http://indonesia.unfpa.org/Gender.

[39] World Bank (2010) Improving Access to Financial Services in Indonesia. Washington DC: The World Bank.

[40] Yin, R. K. (2003).Case Study Research: Design and Methods. London: SAGE Publications.

[41] Zamroni et. Al (2015) Desa Mengembangkan Penghidupan Berkelanjutan Pembelajaran Riset Kolaboratif IRE Yogyakarta dan Pemerintah Daerah Kabupaten Gunungkidul Daerah Istimewa Yogyakarta.Yogyakarta: IRE 